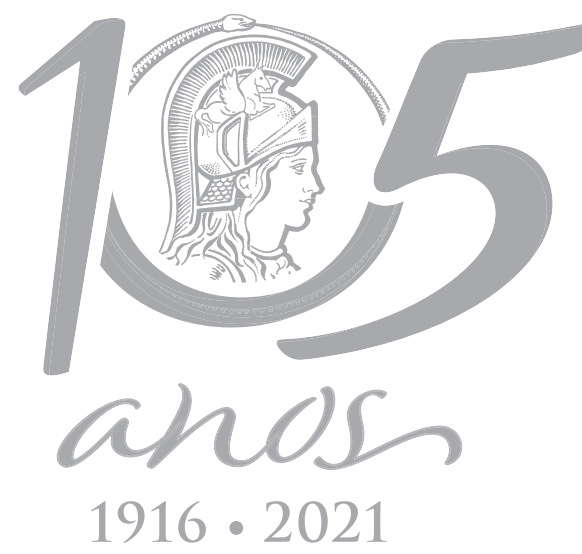

\title{
ECOSYSTEMS
}

\section{Qualitative and quantitative study of parasites of Pimelodus maculatus and Rhamdia quelen from the Jacaré-Pepira River, state of São Paulo, Brazil}

\author{
DÉBORA C. NEGRELLI, JOSÉ IANNACONE, VANESSA D. ABDALLAH \& \\ RODNEY K. DE AZEVEDO
}

\begin{abstract}
In the freshwater ecosystems of Brazil can be found high biodiversity of fish, about 5160 species. However, the Jacaré-Pepira River, located in the state of São Paulo, Brazil, presents a diversity of fish still to be explored in ichthyological studies. Metazoan parasites of Pimelodus maculatus and Rhamdia quelen were qualitatively and quantitatively diagnosed. Ten species of parasites (Demidospermus sp., D. majusculus, D. bidiverticulatum, D. paravalenciennesi, Ameloblastella paranaensis, Scleroductus sp., Riggia sp., Austrodiplostomum compactum, Helobdella sp. and Neochinorhynchus pimelodi) were collected in P. maculatus and eight species of parasites (Aphanoblastella robustus, A. mastigatus, Phyllodistomum rhamdiae, Crocodilicola pseudostoma, Henneguya jundiai, Contracaecum sp., Rhabdochona sp. and Capillariidae gen. sp.) were collected in R. quelen. All parasites presented aggregate distribution. A significant correlation was observed in $P$. maculatus concerning the weight with the prevalence of ectoparasite D. majusculus; however, $R$. quelen showed a relation to the length and weight with the abundance of ectoparasite $A$. mastigatus and endoparasites. The parasitic community of $P$. maculatus and $R$. quelen was characterized by high diversity, high richness, and low uniformity.
\end{abstract}

Key words: biodiversity, ecology, fish, freshwater, Siluriformes.

\section{INTRODUCTION}

The Tietê/Jacaré Hydrographic Basin is located in the center of the state of São Paulo and comprises three main rivers: Tietê, Jacaré-Guaçu, and Jacaré-Pepira. The Jacaré-Pepira River, a study area, known as "Pantaninho", rises on the border between the cities of Brotas and São Pedro and flows into the Tietê River, in the city of Ibitinga, being considered one of the cleanest rivers in the state of São Paulo (Comitê da Bacia Hidrográfica do Rio Jacaré-Pepira 2015).

Brazil is among the countries that have megadiversity, with a considerable amount of species of animals and vegetables, especially in the freshwater and marine environments (Canhos et al. 2015, Reis et al. 2016). In freshwater ecosystems, high biodiversity of fish can be found, about 5160 species (Reis et al. 2016).

The siluriform Pimelodus maculatus Lacepède 1803 is commonly known as "mandi", "mandi-amarelo" or "bagre pintado", has geographical distribution restricted to South America, is characterized as opportunistic species, is active at night, and has an omnivorous feeding habit, and adaptation to a varied diet, consuming seaweed, insects, crustaceans or mollusks (Brasil-Sato \& Pavanelli 2004, 
Bachmann et al. 2007, Albuquerque et al. 2008, Froese \& Pauly 2018) and the siluriform Rhamdia quelen Quoy \& Gaimard 1824 is commonly known as "Jundiá", is distributed in Central and South America, as well as in southern Brazil, has benthonic behavior and nocturnal and omnivorous habit with a carnivorous tendency, thus consuming fish, crustaceans, insects, plants or mollusks (Morais 2005, Vianna et al. 2005, Froese \& Pauly 2018).

Parasitism is vital in ecosystems because it regulates the abundance and density of host populations, stabilizing food chains, and structuring animal communities (Luque \& Poulin 2007). Therefore, it is essential to carry out studies to determine parasitic diversity and consequently contribute to global biodiversity; thus, the objective of this study was to analyze the parasitic fauna of $P$. maculatus and $R$. quelen from the Jacaré-Pepira River, checking the quantitative data, diversity and possible influences of host length, weight, and sex on parasitism.

\section{MATERIALS AND METHODS}

A total of 62 fish specimens were collected in the

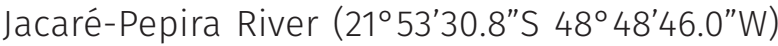
in the city of Ibitinga, state of São Paulo, Brazil. Thirty-two specimens of $P$. maculatus were collected between March and September 2016 and 30 samples of $R$. quelen were collected between January and May 2017 with a simple mesh fishing net under the authorization to capture (SISBio, number 55914-1) and Ethics Committee on the Use of Animals (CEUA, number 9530230816). At the time of collection, the fish were placed in individual plastic bags to avoid changes in their parasitic fauna or loss of materials. The fish were transported in a refrigerated thermal box until they arrived at the laboratory, where they were refrigerated in a freezer until necropsy. At the time of autopsy, information on the collection date, weight (g), standard length $(\mathrm{cm})$, and host sex were recorded.

The parasites were collected and processed according to the procedures indicated by Eiras et al. (2006). The organs were removed individually, the surface of the body, mouth, nostril, and gills were washed with a $53 \mu \mathrm{m}$ sieve for the collection of ectoparasites. Afterward, the eyes and organs of the visceral cavity were washed with a $75 \mu \mathrm{m}$ sieve for the collection of endoparasites. Then, the organs were placed in Petri dishes and observed in a stereomicroscope. The collected parasites were fixed in $70^{\circ} \mathrm{GL}$ ethanol until the time of staining and/or clarification procedures and were mounted between the microscope slide and coverslip.

For identification, the monogeneans were mounted on Grey \& Wess to visualize sclerotized structures, the nematodes were mounted in Amann's Lactophenol, the Isopoda was clarified with lactic acid, and other parasites (Digenea, Acanthocephala, and Hirudinea) were stained with Mayer's Carmalum (Eiras et al. 2006). Digenea were cleared using Eugenol and Acanthocephala and Hirudinea using Beechwood Creosote. The slides were mounted in Canada Balsam and analyzed with the aid of a microscope (Nikon Eclipse E200). After the visualization in the microscope, the species were identified from specific literature for each parasite group. Metacercariae were stained to perform morphological and morphometric analysis, some specimens were also fixed in absolute ethanol to be submitted to molecular biology procedure. For the identification of myxozoan, the cysts still fresh were ruptured between slide and coverslip, and other cysts were fixed in absolute ethanol to perform the molecular biology. 
According to Bush et al. (1997), the quantitative analyzes, such as the prevalence, mean intensity, and mean abundance of each component of the parasite communities were calculated. As also, following the methodology of Rohde et al. (1995), the frequency of dominance of each parasite species was determined by the number of times a parasite species was dominant in all hosts analyzed.

The community status of the parasites was determined according to Caswell (1978) and Hanski (1982), cited by Bush \& Holmes (1986) related to the result of the prevalence of parasite species, therefore, central species are those that are parasitizing more than 66\% of their hosts, secondary species are those that are parasitizing between $33 \%$ and $66 \%$ of their hosts and satellites species are those that are parasitizing less than 33\% of their hosts.

The dispersion index (ID) was calculated to indicate the level of aggregation and the type of distribution of parasitic infrapopulation, however, when ID > 1: aggregate distribution, $I D=1$ : random distribution, and ID < 1: uniform distribution. The statistical test $d$ was calculated to evaluate the significance of the index, however, when $d \geq 1.96$ = aggregate distribution, $d \leq 1.96$ = random distribution, and $d \leq-1.96=$ uniform distribution (Ludwig \& Reynolds 1988).

The following correlations were made by the PAST 3.16 software. Pearson correlation coefficient $(r)$ was performed to determine the possible relationships between parasite abundance with length and weight of the hosts and Spearman correlation coefficient (rs) was performed to determine the possible correlations between parasite prevalence with length and weight of the hosts (Zar 1999).

The ANOVA, Tukey significance, and KruskalWallis tests were applied to analyze the effect of host sex (male, female and immature, due to the time of the fish that could not be verified sex) on total parasite abundance and the Dunn's Post-Hoc test was applied to analyze the effect of host sex (male, female and immature) on the parasite abundance of ectoparasites and endoparasites.

The parasitic diversity was determined for each infracommunity by the Brillouin index $(H)$, richness was determined by the Margalef index $(d)$, equitability was determined by the Pielou uniformity index (J), and dominance was calculated by the Berger-Parker index (d) (Zar 1999).

All tests mentioned were applied only for the parasite species with prevalence more significant than $10 \%$. The results of the statistical analyzes were considered significant when $p$ $<0.05$.

\section{RESULTS}

Pimelodus maculatus specimens (length of $24.90 \pm 2.10 \mathrm{~cm}$ and weight of $407.84 \pm 77.28 \mathrm{~g}$ ) and $R$. quelen specimens (length of $14.93 \pm 4.69$ $\mathrm{cm}$ and weight of $63.05 \pm 76.29 \mathrm{~g}$ ) had previous averages. The weight of $R$. quelen had a standard deviation more significant than the average, due to the intense variation between the fish weight.

Ninety percent of $P$. maculatus specimens and only $26 \%$ of $R$. quelen specimens had at least one species of metazoan parasite. A total of 1796 and 285 parasites were collected from P. maculatus and $R$. quelen, respectively. In $R$. quelen, 11 cysts with myxozoan spores were also collected.

In the P. maculatus specimens, the following groups of metazoan parasites were found: Monogenea,Acanthocephala, Hirudinea, Isopoda, and Digenea. Of these, the monogeneans ( $n=$ 1467) presented higher numbers of specimens about the abundance of the other groups of parasites. Six species of Monogenea were 
identified: Demidospermus majusculus Kritsky \& Gutiérrez 1998, D. bidiverticulatum Suriano \& Incorvaia 1995, D. paravalenciennesi Gutiérrez \& Suriano 1992, Demidospermus sp. Suriano 1983, Ameloblastella paranaensis França, Isaac, Pavanelli \& Takemoto 2003, Scleroductus sp. Jara \& Cone 1989 parasitizing the gills and surface of hosts. A single specimen of isopod, Riggia sp. Szidat 1948, measuring $1.75 \times 0.64 \mathrm{~mm}$, was found on the surface. A species belonging to subclass Digenea was collected as a metacercaria parasitizing the eyes and identified as Austrodiplostomum compactum Lutz 1928. Hirudinean of the genus Helobdella Blanchard 1896 were found parasitizing the surface, gills, and mouth. Also, in these fish were found acanthocephalans Neochinorhynchus pimelodi Brasil-Sato \& Pavanelli 1998 parasitizing the intestine and stomach of the hosts. In the $R$. quelen specimens, the following groups of metazoan parasites were found: Monogenea, Digenea, Nematoda, and Myxosporea. Of these, monogeneans $(n=206)$ also presented higher numbers of specimens with the abundance of the other groups of parasites. Two species of Monogenea were identified: Aphanoblastella robustus Mizelle \& Kritsky 1969 and A. mastigatus Suriano 1986 parasitizing the gills and surface. A single specimen belonging to the Digenea subclass was identified parasitizing the liver of only one host: Phyllodistomum rhamdiae Amato \& Amato 1993. Likewise, a progenetic metacercariae of Crocodilicola pseudostoma Willemoes-Suhm 1870 was identified in only one host parasitizing the liver, swimming bladder, cavity, intestine, and stomach. Cysts containing myxozoan spores of the Henneguya jundiai Negrelli, Vieira, Tagliavini, Abdallah \& Azevedo 2019 were found in the gill arches and three species belonging to the Nematoda phylum were collected in the intestine and cavity of only one specimen of host: Contracaecum sp. Railliet
\& Henry 1912, Rhabdochona sp. Railliet 1916 and Capillariidae gen. sp. Railliet 1915.

The prevalence, mean intensity, mean abundance, and frequency dominance was higher for Scleroductus sp. (Table I) in P. maculatus. In $R$. quelen, the monogenean A. robustus had higher prevalence, mean abundance, and frequency dominance; however, the metacercaria C. pseudostoma had higher mean intensity (Table II).

Scleroductus sp. was considered a central species, $N$. pimelodi was considered a secondary species, and all the other parasite species were considered satellites. All parasites had aggregate distribution (Table III).

The results obtained by Pearson $(r)$ and Spearman (rs) correlation coefficient showed that had the positive correlations in relation to weight of the P. maculatus with the prevalence of D. majusculus ( $r s=0.87, p=0.03$ ); however, in $R$. quelen was observed positive correlation to the length and weight with the abundance of endoparasites $(r=0.63, p=0.00 ; r=0.87, p<0.05$ ) and with the parasite $A$. mastigatus ( $r=0.51, p=$ $0.00 ; r=0.68, p<0.05)$.

The results obtained by ANOVA $(F=4.12$, $p=0.03)$, Tukey significance $(Q=4.28, P=0.01)$ and Kruskal-Wallis $(H=4.90, p=0.09)$ tests showed significance with male specimens of $P$. maculatus. However, in $R$. quelen the results by ANOVA ( $F=0.18, p=0.84)$, Tukey significance ( $p$ > $0.05)$ and Kruskal-Wallis $(H=0.91, p=0.50)$ tests showed no significance.

The results for the Dunn's Post-Hoc test, which, the effect sex of the P. maculatus and $R$. quelen with the ectoparasite abundance ( $p=$ $0.03)(p=0.04)$ respectively, showed significance with immature specimens of both host species and with endoparasites abundance $(p>0.05)$ showed no significance.

The parasitic diversity indexes determined for each parasitic infracommunity of hosts $P$. 
Table I. Metazoan parasites of Pimelodus maculatus Lacépède, 1803 collected in the Jacaré-Pepira River, Ibitinga, state of São Paulo, Brazil.

\begin{tabular}{|c|c|c|c|c|c|c|c|c|}
\hline & & PF & PC & $\mathbf{P}(\%)$ & FD (\%) & MI & MA & II \\
\hline \multirow[t]{6}{*}{ Monogenea } & $\begin{array}{l}\text { Demidospermus } \\
\text { majusculus }\end{array}$ & 6 & 95 & 18.75 & 6.25 & $\begin{array}{c}15.83^{ \pm} \\
1.24\end{array}$ & $\begin{array}{l}2.97^{ \pm} \\
0.23\end{array}$ & Gills and surface \\
\hline & $\begin{array}{l}\text { Demidospermus } \\
\text { bidiverticulatum }\end{array}$ & 7 & 55 & 21.88 & 3.13 & $\begin{array}{c}7.86^{ \pm} \\
0.47\end{array}$ & $\begin{array}{l}1.72^{ \pm} \\
0.10\end{array}$ & Gills and surface \\
\hline & Demidospermus sp. & 6 & 56 & 18.75 & 3.13 & $\begin{array}{c}9.33^{ \pm} \\
0.65\end{array}$ & $\begin{array}{c}1.75^{ \pm} \\
0.12\end{array}$ & Gills and surface \\
\hline & $\begin{array}{l}\text { Demidospermus } \\
\text { paravalenciennesi }\end{array}$ & 1 & 8 & 3.13 & 0 & 8.00 & $\begin{array}{l}0.25^{ \pm} \\
0.04\end{array}$ & Gills and surface \\
\hline & $\begin{array}{c}\text { Ameloblastella } \\
\text { paranaensis }\end{array}$ & 4 & 71 & 12.50 & 3.13 & $\begin{array}{c}17.75^{ \pm} \\
1.88\end{array}$ & $\begin{array}{l}2.22 \pm \\
0.23\end{array}$ & Gills and surface \\
\hline & Scleroductus sp. & 25 & 1182 & 78.13 & 75.00 & $\begin{array}{c}47.28^{ \pm} \\
1.54\end{array}$ & $\begin{array}{c}36.94^{ \pm} \\
1.20\end{array}$ & Gills and surface \\
\hline Acanthocephala & $\begin{array}{l}\text { Neochinorhynchus } \\
\text { pimelodi }\end{array}$ & 21 & 165 & 65.63 & 9.38 & $\begin{array}{c}7.86^{ \pm} \\
0.42\end{array}$ & $\begin{array}{l}5.16^{ \pm} \\
0.28\end{array}$ & $\begin{array}{l}\text { Intestine and } \\
\text { stomach }\end{array}$ \\
\hline Digenea & $\begin{array}{l}\text { Austrodiplostomum } \\
\text { compactum }\end{array}$ & 4 & 7 & 12.50 & 0 & $\begin{array}{l}1.75^{ \pm} \\
0.16\end{array}$ & $\begin{array}{l}0.22 \pm \\
0.02\end{array}$ & Eyes \\
\hline Hirudinea & Helobdella sp. & 7 & 156 & 21.88 & 6.25 & $\begin{array}{c}22.29 \pm \\
2.89\end{array}$ & $\begin{array}{c}4.88^{ \pm} \\
0.63\end{array}$ & $\begin{array}{c}\text { Surface, gills and } \\
\text { mouth }\end{array}$ \\
\hline Isopoda & Riggia sp. & 1 & 1 & 3.13 & 0 & 1.00 & $\begin{array}{c}0.03^{ \pm} \\
0.01\end{array}$ & Surface \\
\hline
\end{tabular}

$\mathrm{PF}=$ number of parasitized fish; $\mathrm{PC}=$ number of parasites collected; $\mathrm{P}(\%)=$ prevalence; $\mathrm{FD}=$ frequency of dominance; $\mathrm{MI}=$ mean intensity with standard deviation; $M A$ = mean abundance with standard deviation; II = site of infestation/infection.

maculatus and R. quelen: Brillouin (diversity); Margalef (richness); Pielou (equitability) and Berger-Parker (dominance) are presented in Table IV.

Representative specimens of the parasites Demidospermus majusculus (346L), D. bidiverticulatum (347L), Demidospermus sp. (348L), D. paravalenciennesi (349L), Ameloblastella paranaensis (350L), Scleroductus sp. (351L), Neochinorhynchus pimelodi (352L), Austrodiplostomum compactum (353L), Helobdella sp. (354L), Aphanoblastella robustus (355L), A. mastigatus (356L), Crocodilicola pseudostoma (357L), Phyllodistomum rhamdiae (358L), Riggia sp. (8187), Contracaecum sp. (8188) were deposited in the helminthological collection of the Instituto de Biociências, at the Universidade Estadual Paulista "Julio de Mesquita Filho", campus Botucatu, state of São Paulo, Brazil.

\section{DISCUSSION}

The parasitic community of $P$. maculatus and $R$. quelen was studied by some authors in different hydrological systems (Table V).

According to Halvorsen (1971) and Wootten (1973) the relationship between hosts and parasites is constant, even if they have limnological or geographical differences; thus, we can observe in the present study that there 
Table II. Metazoan parasites of Rhamdia quelen Quoy \& Gaimard, 1824 collected in the Jacaré-Pepira River, Ibitinga, state of São Paulo, Brazil.

\begin{tabular}{|c|c|c|c|c|c|c|c|c|}
\hline & & PF & PC & $\mathrm{P}(\%)$ & $\mathrm{FD}(\%)$ & MI & MA & II \\
\hline \multirow[t]{2}{*}{ Monogenea } & $\begin{array}{c}\text { Aphanoblastella } \\
\text { robustus }\end{array}$ & 5 & 119 & 16.67 & 16.67 & $\begin{array}{c}23.80^{ \pm} \\
3.54\end{array}$ & $\begin{array}{c}3.97 \pm \\
0.59\end{array}$ & Gills and surface \\
\hline & $\begin{array}{c}\text { Aphanoblastella } \\
\text { mastigatus }\end{array}$ & 4 & 87 & 13.33 & 6.67 & $\begin{array}{c}21.75^{ \pm} \\
2.39\end{array}$ & $\begin{array}{c}2.90 \pm \\
0.32\end{array}$ & Gills and surface \\
\hline \multirow[t]{2}{*}{ Digenea } & $\begin{array}{l}\text { Crocodilicola } \\
\text { pseudostoma }\end{array}$ & 1 & 68 & 3.33 & 3.33 & 68.00 & $\begin{array}{c}2.27 \pm \\
0.41\end{array}$ & $\begin{array}{l}\text { Liver, swim bladder, } \\
\text { cavity, intestine } \\
\text { and stomach }\end{array}$ \\
\hline & $\begin{array}{l}\text { Phyllodistomum } \\
\text { rhamdiae }\end{array}$ & 1 & 1 & 3.33 & 3.33 & 1.00 & $\begin{array}{l}0.03 \pm \\
0.01\end{array}$ & Liver \\
\hline Myxosporea & $\begin{array}{l}\text { Henneguya } \\
\text { jundiai }\end{array}$ & 3 & - & 10.00 & - & - & - & Gill arches \\
\hline \multirow[t]{3}{*}{ Nematoda } & $\begin{array}{c}\text { Contracaecum } \\
\text { sp. }\end{array}$ & 1 & 8 & 3.33 & 0.00 & 8.00 & $\begin{array}{l}0.27^{ \pm} \\
0.05\end{array}$ & $\begin{array}{l}\text { Cavity and } \\
\text { intestine }\end{array}$ \\
\hline & $\begin{array}{l}\text { Capillariidae } \\
\text { gen. sp. }\end{array}$ & 1 & 1 & 3.33 & 0.00 & 1.00 & $\begin{array}{l}0.03 \pm \\
0.01\end{array}$ & Cavity \\
\hline & $\begin{array}{l}\text { Rhabdochona } \\
\text { sp. }\end{array}$ & 1 & 1 & 3.33 & 0.00 & 1.00 & $\begin{array}{l}0.03 \pm \\
0.01\end{array}$ & Cavity \\
\hline
\end{tabular}

$\mathrm{PF}=$ number of parasitized fish; $\mathrm{PC}=$ number of parasites collected; $\mathrm{P}(\%)=$ prevalence; $\mathrm{FD}=$ frequency of dominance; $\mathrm{MI}=$ mean intensity with standard deviation; MA = mean abundance with standard deviation; II = site of infestation/infection.

is a similarity in the parasitic groups of $P$. maculatus and $R$. quelen compared to the other basins already studied.

The structure of the parasitic community of $P$. maculatus and $R$. quelen was analyzed from the hypothesis of Caswell (1978) and Hanski (1982, 1991), in which they determined the community status of the parasites and suggested that the central species are abundant to achieve equilibrium, but satellite species are less abundant and consequently are not very frequent in the parasitic community (Bush \& Holmes 1986), while, the secondary species are those intermediate between the central and satellite species in terms of parasite abundance.

The parasitic community of P. maculatus and $R$. quelen presented a typical distribution pattern (aggregate). In general, in the studies of parasite infections in vertebrate hosts, it is common for parasites to show the aggregate distribution in their hosts. This distribution pattern is considered typical in freshwater fish parasites; however, this distribution acts to increase the regulation of the density and abundance of hosts and parasites and also to decrease interspecific competition among parasites (Von Zuben 1997). The leading cause of aggregate distribution is related to random environmental factors, such as the physical changes of the environment in time and space and the hosts' sensitivity to the infection, is associated with the immunological, behavioral, or microhabitat alterations and genetic factors; therefore, changes in microhabitats and hereditary factors may influence the mortality of both parasites and hosts and may also develop 
Table III. Dispersion index (ID) and statistical test $d$ of the metazoan parasites (with a prevalence greater than $10 \%$ ) of Pimelodus maculatus Lacépède, 1803 and Rhamdia quelen Quoy \& Gaimard, 1824 collected in the Jacaré-Pepira River, Ibitinga, state of São Paulo, Brazil.

\begin{tabular}{|l|c|c|c|c|}
\hline & & ID & d & Distribution \\
\hline Pimelodus maculatus & Demidospermus majusculus & 18.50 & 26.06 & Aggregate \\
\hline & Demidospermus bidiverticulatum & 6.35 & 12.03 & Aggregate \\
\hline & Demidospermus sp. & 8.81 & 15.56 & Aggregate \\
\hline & Ameloblastella paranaensis & 25.41 & 31.87 & Aggregate \\
\hline & Scleroductus sp. & 39.89 & 41.92 & Aggregate \\
\hline & Neochinorhynchus pimelodi & 15.25 & 22.93 & Aggregate \\
\hline & Austrodiplostomum compactum & 1.99 & 3.26 & Aggregate \\
\hline & Helobdella sp. & 83.87 & 64.27 & Aggregate \\
\hline & & & & \\
\hline Rhamdia quelen & Aphanoblastella robustus & 79.07 & 60.17 & Aggregate \\
\hline & Aphanoblastella mastigatus & 31.42 & 35.14 & Aggregate \\
\hline
\end{tabular}

diversity in the dispersion of parasites within the host population (Von Zuben 1997). Anderson \& Gordon (1982) proposed that the aggregation levels of the parasites present inversely proportional variation to the pathogenicity of the parasite because the highly pathogenic parasites have a higher possibility of causing the death of the hosts that show medium or high levels of parasites and with this cause, a uniform distribution of the pests, reducing the aggregation of the parasites in their hosts. According to these authors, the factors that generate the uniform distribution are the mortality of parasites, density-dependent processes as well as death of the host when caused by the parasite, that is, when the host death occurs due to the high parasitic load, however, concerning the factors that generate the aggregate distribution is involved the diversity in the tendency of the host to the infection, direct reproduction of the parasite in the host, as well as the diversity of the ability of the hosts to eliminate the parasites by immunological responses.

The length and weight of $R$. quelen correlated with the abundance of endoparasites and this result was obtained because all the endoparasites were collected only in two hosts, whose which presented longer length (23.50 and $30.50 \mathrm{~cm}$ ) and higher weight (171.05 and 414.61 g) concerning other specimens of fish analyzed. We can verify the influence of the length of $R$. quelen specimens with the abundance of endoparasites, and according to Von Zuben (1997) the range of the host is one of the main factors correlated with the parasite abundance because the larger length hosts often have a higher food consumption compared to hosts with smaller length and the larger length hosts can provide more space for the parasites to lodged and consequently lodged several species. The age of the host is demonstrated concerning the length 
and this mainly acts in the variation of the size of the parasitic infrapopulation, however these variations in the parasitic fauna according to the age of the hosts can also be related to immunological and ecological factors, like alteration in the diet and fish migration (Dogiel 1961). According to Bell \& Burt (1991), the diversity of endoparasites may be related to the size, age, and diet of the host; however, this relationship between endoparasite diversity and host length indicates that there are significant variations in food habits of the host according to its growth.

In P. maculatus, ectoparasites and endoparasites were more abundant in immature specimens. However, the juvenile specimens of $R$. quelen presented lower parasitic abundance, ectoparasites were more abundant in males, while endoparasites were more abundant in females.

There are several studies carried out in Brazil (Saad \& Luque 2009, Dias et al. 2010, Fontenelle et al. 2015, Rodrigues et al. 2015, Santos \& Alves 2016, Serrano et al. 2017), as well as in other countries (Grabda 1983, Chao 1985, Mattiucci et al. 2002, Fei et al. 2004, Su \& Fei 2004, Kozačinski et al. 2006, Iglesias et al. 2008, Palm et al. 2008), in which they reported that the fish were parasitized by nematodes with zoonotic potential, main nematodes of the family Anisakidae.

The nematodes of the genus Contracaecum belong to the family Anisakidae and are economically essential parasites because they have zoonotic potential, this genus parasite the fish as larvae, that is, it uses the fish as an intermediate host. However, these parasites when adults lodged in the stomach/intestine of piscivorous birds or marine mammals. The larvae of Contracaecum regularly adhering to the viscera of the fish can migrate to the muscle after the death of the host, this occurs when the fish are not frozen at the optimal temperature
(Bier 1988, Carvalho et al. 2010, Souza et al. 2016). However, it is vital to take the necessary care when preparing and consuming raw or undercooked fish, such as "sushi," "sashimi" and "ceviche", because the larvae $\left(L_{3}\right)$ of the parasite may cause a parasitic syndrome in humans, that is, anisakidosis. The pathology in humans will depend on the region or location in which the larva of the parasite will lodge, thus, the disease may be luminal when the worms are deposited inside the organs asymptomatically without causing damage, and after the larva's death it will be eliminated in the feces (Ramos 2011, Souza et al. 2016); when the worm lodged is in the gastrointestinal tract can cause pain, diarrhea, and nausea; in some cases when larvae are deposited in the wall of the mucosa, may manifest allergic reactions due to the toxins produced by the parasite (Moneo et al. 2000, Martins et al. 2005, Souza et al. 2016, Shamsi et al. 2018) and in cases of chronic subacute form, the larvae may migrate and lodged to other organs such as lung, liver, spleen, and pancreas (Nunes et al. 2003, Souza et al. 2016). In Brazil, there is only one report of anisakidosis in humans, in which the contaminated person consumed raw shellfish in Bahia state three weeks before the symptoms (Cruz et al. 2010) and according to Kim et al. (2006) the absence of other reports in Brazil may be related to the difficulty of diagnosing the disease, because the case is confirmed only when through the diagnosis, it visualizes the presence of larvae of the parasite of the family Anisakidae.

Dias et al. (2016) studied the helminth parasites in southern Brazil, in which they also found nematodes of the genus Contracaecum anisakids, the infections may be related to the environmental factors, such as temperature, that may influence the development of parasite eggs, as well as other factors, such as the age, size, and diet of hosts (Torres et al. 2000, Carvalho 
Table IV. Parasite diversity indexes determined for the parasitic infracommunity of Pimelodus maculatus Lacépède, 1803 and Rhamdia quelen Quoy \& Gaimard, 1824 collected in the Jacaré-Pepira River, Ibitinga, state of São Paulo, Brazil.

\begin{tabular}{|c|c|c|}
\hline & $\begin{array}{c}\text { Pimelodus } \\
\text { maculatus }\end{array}$ & $\begin{array}{c}\text { Rhamdia } \\
\text { quelen }\end{array}$ \\
\hline Brillouin (H) & $1.18 \pm 1.30(1.24)$ & $1.12 \pm 1.26(1.19)$ \\
\hline Margalef (d) & $1.20 \pm 1.20(1.20)$ & $0.88 \pm 1.06(1.06)$ \\
\hline Pielou (J) & $0.52 \pm 0.57(0.54)$ & $0.61 \pm 0.70(0.63)$ \\
\hline $\begin{array}{c}\text { Berger-Parker } \\
\text { (d) }\end{array}$ & $0.68 \pm 0.30(0.66)$ & $0.30 \pm 0.47(0.42)$ \\
\hline
\end{tabular}

Values in parentheses are the mean.

et al. 2015). Madi \& Silva (2005) analyzed the infections of the parasite Contracaecum sp. in $R$. quelen and was observed that the presence of this parasite is more intense in fish with longer length than $20.00 \mathrm{~cm}$ (Carvalho et al. 2015), we can also find this in the present study because the host parasitized by Contracaecum sp. was the most extended $(30.50 \mathrm{~cm})$ about the other 29 fish analyzed.

According to parasitic diversity indexes results, indicate that the parasitic community of $P$. maculatus and $R$. quelen is characterized by high diversity, high richness, and low uniformity, this can be explained by the high number of parasite species found in both species of fish; P. maculatus (10 species) and R. quelen (eight species) and also for the high abundance found in most species of parasites, however, obtained a low uniformity because the parasites presented an aggregate distribution. According to Bush et al. (1997) the meaning of diversity in the composition of a community in terms of the number of species present and some factor that changes the relative equality of the distribution of each species because the species are not the same, some may have a high, medium or rare abundance. Besides, this diversity can be divided into richness, which is the number of species present in a single host and in uniformity, in which it reports how much the abundance of the species is variable, in this case, a community in which all species has the approximately same number of individuals can be considered with high uniformity and when there is a significant difference in the abundance of the species has the effect of a low uniformity (Magurran 1988). According to Von Zuben (1997), the diversity of parasites may also be related to the variety of intermediate and definitive hosts.

The mean of the Berger-Parker dominance index was higher in the host P. maculatus 0.68 \pm 0.30 compared to the $R$. quelen host $0.30 \pm$ 0.47, and according to Ingram (2008) the BergerParker dominance index determines the higher abundance of individuals in the species of parasite that presented in the ecological community; thus, P. maculatus had parasite species that showed a higher richness, compared to the abundance of the parasite species collected in $R$. quelen.

In the two species of fish analyzed, ectoparasites were more prevalent compared to endoparasites. According to Pavanelli et al. (2004), the monogeneans are more frequent in environments considered lentic, because these environments contribute to the transmission of these parasites that have a direct life cycle so that free-swimming monogenean larvae to find the host more easily (Dogiel 1961). According to Kennedy (1982), abiotic factors such as depth, habitat, pollution, and temperature of rivers, are the main that affect abundance and prevalence parasitic. Thus, the predominance of monogeneans in P. maculatus and R. quelen may be related to the habitat of these hosts collected in a lentic environment and also for the habit of these fish, because they remain at the bottom of the rivers, providing a greater contact with the monogeneans. 
Table V. World checklist of parasites of Pimelodus maculatus Lacepède, 1803 and Rhamdia quelen Quoy \& Gaimard, 1824.

\begin{tabular}{|c|c|c|c|c|}
\hline Parasites & Host & $\begin{array}{l}\text { infection / } \\
\text { infestation }\end{array}$ & Locality & Reference \\
\hline \multicolumn{5}{|c|}{ Acanthocephala } \\
\hline $\begin{array}{l}\text { Pomphorhynchus } \\
\text { sphaericus }\end{array}$ & PM & - & Argentina & Pertierra et al. (1996) \\
\hline $\begin{array}{l}\text { Neoechinorhynchus } \\
\text { pimelodi }\end{array}$ & PM & Intestine & Brazil & $\begin{array}{l}\text { Brasil-Sato \& Pavanelli }(1998,1999), \text { Lopes et } \\
\text { al. (2011) }\end{array}$ \\
\hline $\begin{array}{l}\text { Neoechinorhynchus } \\
\text { sp. }\end{array}$ & $\mathrm{RQ}$ & Intestine & Brazil & Morais (2005) \\
\hline $\begin{array}{l}\text { Quadrigyrus } \\
\text { machadoi }\end{array}$ & PM & Intestine & $\begin{array}{l}\text { Brazil and } \\
\text { Argentina }\end{array}$ & $\begin{array}{l}\text { Takemoto et al. (2009), Chemes \& Brusa } \\
\text { (2013) }\end{array}$ \\
\hline Polymorphus sp. & $\mathrm{RQ}$ & Intestine & Brazil & Morais (2005), Azevedo et al. (2010) \\
\hline Centrorhynchus sp. & $\mathrm{RQ}$ & Mesentery & Brazil & Morais (2005) \\
\hline \multicolumn{5}{|c|}{ Hirudinea } \\
\hline Helobdella sp. & PM & Gill & Brazil & $\begin{array}{l}\text { Brasil-Sato (2003), Santos et al. (2007), } \\
\text { Takemoto et al. (2009) }\end{array}$ \\
\hline Myzobdella sp. & PM & Gill & Brazil & Brasil-Sato (2003), Takemoto et al. (2009) \\
\hline $\begin{array}{l}\text { Myzobdella } \\
\text { uruguaiensis }\end{array}$ & $\mathrm{RQ}$ & Gill & Brazil & Morais (2005) \\
\hline \multicolumn{5}{|c|}{ Copepoda } \\
\hline $\begin{array}{l}\text { Ergasilus } \\
\text { chelangulatus }\end{array}$ & PM & Gill & Brazil & Thatcher \& Brasil-Sato (2008) \\
\hline Ergasilus thatcheri & $\mathrm{RQ}$ & Gill & Brazil & Engers et al. (2000) \\
\hline $\begin{array}{l}\text { Gamispinus } \\
\text { diabolicus }\end{array}$ & PM & Nasal cavitie & Brazil & $\begin{array}{c}\text { Brasil-Sato et al. (2000), Brasil-Sato (2003), } \\
\text { Luque et al. (2013) }\end{array}$ \\
\hline Gamidactylus sp. & PM & - & Brazil & Takemoto et al. (2009), Luque et al. (2013) \\
\hline Therodamas sp. & PM & Gill & Brazil & $\begin{array}{c}\text { Brasil-Sato (2003), Takemoto et al. (2009), } \\
\text { Luque et al. (2013) }\end{array}$ \\
\hline Vaigamus sp. & PM & - & Brazil & $\begin{array}{c}\text { Brasil-Sato (2003), Takemoto et al. (2009), } \\
\text { Luque et al. (2013) }\end{array}$ \\
\hline Lernaea cyprinacea & $\mathrm{RQ}$ & $\begin{array}{l}\text { Pectoral fins and } \\
\text { buccal cavity }\end{array}$ & Brazil & Furtado et al. (2019) \\
\hline \multicolumn{5}{|c|}{ Isopoda } \\
\hline Telotha sp. & PM & Gill & Brazil & Brasil-Sato (2003), Takemoto et al. (2009) \\
\hline Riggia sp. & $\mathrm{RQ}$ & Abdominal cavity & Ecuador & Anaguano-Yancha \& Brito (2015) \\
\hline \multicolumn{5}{|c|}{ Cestoda } \\
\hline Endorchis sp. & PM & Intestine & Paraguay & Chambrier \& Vaucher (1999) \\
\hline Monticellia loyolai & PM & Intestine & Brazil & $\begin{array}{c}\text { Pavanelli \& Machado dos Santos (1992), } \\
\text { Brasil-Sato (2003) }\end{array}$ \\
\hline
\end{tabular}


Table V. Continuation

\begin{tabular}{|c|c|c|c|c|}
\hline Parasites & Host & $\begin{array}{l}\text { infection / } \\
\text { infestation }\end{array}$ & Locality & Reference \\
\hline $\begin{array}{l}\text { Nomimoscolex } \\
\text { microacetabula }\end{array}$ & PM & Intestine & Argentina & Pertierra (1995) \\
\hline $\begin{array}{l}\text { Nomimoscolex } \\
\text { pimelodi }\end{array}$ & PM & Intestine & Argentina & Pertierra (1995) \\
\hline Nomimoscolex sp. & PM & Intestine & Brazil & $\begin{array}{c}\text { Brasil-Sato (2003), Santos et al. (2007), } \\
\text { Albuquerque et al. (2008), Takemoto et al. } \\
\text { (2009), Azevedo et al. (2010) }\end{array}$ \\
\hline Monticellia magna & PM & Intestine & Argentina & Pertierra (2004) \\
\hline $\begin{array}{l}\text { Goezeella } \\
\text { agostinhoi }\end{array}$ & PM & Intestine & Brazil & Bachmann et al. (2007) \\
\hline Valipora sp. & PM & Gallbladder & Brazil & Takemoto et al. (2009) \\
\hline $\begin{array}{l}\text { Proteocephalus } \\
\text { bagri }\end{array}$ & $\mathrm{RQ}$ & Intestine & Argentina & Pertierra (2002) \\
\hline $\begin{array}{l}\text { Proteocephalus } \\
\text { rhamdiae }\end{array}$ & $\mathrm{RQ}$ & Intestine & Argentina & Pertierra (2002) \\
\hline \multicolumn{5}{|c|}{ Digenea } \\
\hline $\begin{array}{l}\text { Crepidostomum } \\
\text { platense }\end{array}$ & PM & $\begin{array}{l}\text { Estomach and } \\
\text { intestine }\end{array}$ & $\begin{array}{l}\text { Brazil and } \\
\text { Argentina }\end{array}$ & $\begin{array}{c}\text { Kohn \& Fróes (1986), Brasil-Sato (2003), } \\
\text { Brasil-Sato \& Pavanelli (2004), Takemoto et } \\
\text { al. (2009), Núñez et al. (2017) }\end{array}$ \\
\hline $\begin{array}{l}\text { Creptotrema } \\
\text { creptotrema }\end{array}$ & PM & Intestine & Brazil & $\begin{array}{c}\text { Kohn \& Fróes (1986), Brasil-Sato (2003), } \\
\text { Brasil-Sato \& Pavanelli (2004), Takemoto et } \\
\text { al. (2009) }\end{array}$ \\
\hline $\begin{array}{l}\text { Parspina } \\
\text { argentinensis }\end{array}$ & PM & $\begin{array}{l}\text { Estomach and } \\
\text { intestine }\end{array}$ & $\begin{array}{l}\text { Brazil and } \\
\text { Argentina }\end{array}$ & $\begin{array}{c}\text { Kohn \& Fróes (1986), Bachmann et al. (2007), } \\
\text { Núñez et al. (2017) }\end{array}$ \\
\hline $\begin{array}{l}\text { Thometrema } \\
\text { overstreeti }\end{array}$ & PM & $\begin{array}{l}\text { Estomach and } \\
\text { intestine }\end{array}$ & Brazil & $\begin{array}{l}\text { Kohn et al. (1990), Brasil-Sato (2003), Brasil- } \\
\text { Sato \& Pavanelli (2004), Takemoto et al. } \\
\text { (2009) }\end{array}$ \\
\hline Plehniella coelomica & PM & $\begin{array}{l}\text { Cavity } \\
\text { celomatic }\end{array}$ & Brazil & $\begin{array}{c}\text { Brasil-Sato (2003), Brasil-Sato \& Pavanelli } \\
\text { (2004), Takemoto et al. (2009) }\end{array}$ \\
\hline $\begin{array}{l}\text { Prosthenhystera } \\
\text { obesa }\end{array}$ & PM & Gallbladder & Brazil & $\begin{array}{l}\text { Brasil-Sato (2003), Brasil-Sato \& Pavanelli } \\
\text { (2004), Takemoto et al. (2009) }\end{array}$ \\
\hline Clinostomum sp. & PM & Gill Muscle & Brazil & $\begin{array}{l}\text { Brasil-Sato (2003), Brasil-Sato \& Pavanelli } \\
\text { (2004), Takemoto et al. (2009) }\end{array}$ \\
\hline $\begin{array}{l}\text { Clinostomum } \\
\text { complanatum }\end{array}$ & $\mathrm{RQ}$ & $\begin{array}{l}\text { Muscle, gill, fins and } \\
\text { eyes }\end{array}$ & Brazil & $\begin{array}{l}\text { Morais (2005), Vianna et al. (2005), Dias et al. } \\
\text { (2016) }\end{array}$ \\
\hline $\begin{array}{l}\text { Clinostomum } \\
\text { detruncatum }\end{array}$ & $\mathrm{RQ}$ & - & Brazil & Azevedo et al. (2010) \\
\hline Diplostomum sp. & PM & $\begin{array}{c}\text { Eyes, } \\
\text { cephalic renal } \\
\text { parenchyma, bladder } \\
\text { musculature and } \\
\text { pharyngeal plate }\end{array}$ & Brazil & $\begin{array}{c}\text { Brasil-Sato (2003), Brasil-Sato \& Pavanelli } \\
\text { (2004), Bachmann et al. (2007), Takemoto et } \\
\text { al. (2009) }\end{array}$ \\
\hline
\end{tabular}


Table V. Continuation

\begin{tabular}{|c|c|c|c|c|}
\hline Parasites & Host & $\begin{array}{l}\text { infection / } \\
\text { infestation }\end{array}$ & Locality & Reference \\
\hline $\begin{array}{l}\text { Austrodiplostomum } \\
\text { compactum }\end{array}$ & PM & Eyes & Brazil & Santos et al. (2007) \\
\hline Genarchella parva & $\begin{array}{c}\mathrm{PM} / \\
\mathrm{RQ}\end{array}$ & Stomach & - & Núñez et al. (2017) \\
\hline Genarchella sp. & $\mathrm{RQ}$ & Stomach, intestine & Brazil & Morais (2005), Dias et al. (2016) \\
\hline $\begin{array}{l}\text { Crocodilicola } \\
\text { pseudostoma }\end{array}$ & $\mathrm{RQ}$ & Body cavity & Brazil & Armas de Conroy (1986) \\
\hline $\begin{array}{l}\text { Phyllodistomum } \\
\text { rhamdiae }\end{array}$ & $\mathrm{RQ}$ & Urinary bladder & Brazil & Amato \& Amato (1993) \\
\hline $\begin{array}{l}\text { Tylodelphys } \\
\text { destructor }\end{array}$ & $\mathrm{RQ}$ & $\begin{array}{l}\text { Celtic cavity, cephalic } \\
\text { kidney, heart, swim } \\
\text { bladder, gonad and } \\
\text { intestine }\end{array}$ & Brazil & Morais (2005), Dias et al. (2016) \\
\hline Acanthostomum sp. & $\mathrm{RQ}$ & $\begin{array}{l}\text { Stomach and } \\
\text { intestine }\end{array}$ & Brazil & Morais (2005), Dias et al. (2016) \\
\hline \multicolumn{5}{|c|}{ Monogenea } \\
\hline $\begin{array}{l}\text { Ameloblastella } \\
\text { platensis }\end{array}$ & PM & Gill & $\begin{array}{l}\text { Argentina } \\
\text { and Brazil }\end{array}$ & $\begin{array}{l}\text { Suriano \& Incorvaia (1995), Monteiro et al. } \\
\qquad(2010)\end{array}$ \\
\hline $\begin{array}{l}\text { Ameloblastella } \\
\text { paranaensis }\end{array}$ & PM & Gill & Brazil & Monteiro et al. (2010) \\
\hline Ameloblastella satoi & PM & Gill & Brazil & Monteiro et al. (2010) \\
\hline $\begin{array}{l}\text { Ameloblastella } \\
\text { chavarriai }\end{array}$ & $\mathrm{RQ}$ & Gill & - & Thatcher (2006) \\
\hline Aphanoblastella sp. & $\begin{array}{l}\mathrm{PM} / \\
\mathrm{RQ}\end{array}$ & Gill & Brazil & Venancio et al. (2010) \\
\hline $\begin{array}{l}\text { Aphanoblastella } \\
\text { juizforense }\end{array}$ & $\mathrm{RQ}$ & Gill & Brazil & Carvalho et al. (2009) \\
\hline $\begin{array}{l}\text { Aphanoblastella } \\
\text { mastigatus }\end{array}$ & $\mathrm{RQ}$ & Gill & Brazil & Azevedo et al. (2010) \\
\hline Demidospermus sp. & PM & Gill & Brazil & Brasil-Sato (2003), Takemoto et al. (2009) \\
\hline $\begin{array}{l}\text { Demidospermus } \\
\text { bidiverticulatum }\end{array}$ & PM & Gill & $\begin{array}{l}\text { Argentina } \\
\text { and Brazil }\end{array}$ & $\begin{array}{c}\text { Kritsky \& Gutiérrez (1998), Gutiérrez \& } \\
\text { Martorelli (1999a, b), Cohen \& Kohn (2008), } \\
\text { Monteiro et al. (2010) }\end{array}$ \\
\hline $\begin{array}{l}\text { Demidospermus } \\
\text { paravalenciennesi }\end{array}$ & PM & Gill & $\begin{array}{l}\text { Argentina } \\
\text { and Brazil }\end{array}$ & $\begin{array}{c}\text { Kritsky \& Gutiérrez (1998), Gutiérrez \& } \\
\text { Martorelli (1999a, b), Santos et al. (2007), } \\
\text { Cohen \& Kohn (2008), Azevedo et al. (2010), } \\
\text { Monteiro et al. (2010) }\end{array}$ \\
\hline $\begin{array}{l}\text { Demidospermus } \\
\text { uncusvalidus }\end{array}$ & PM & Gill & $\begin{array}{l}\text { Argentina } \\
\text { and Brazil }\end{array}$ & $\begin{array}{c}\text { Kritsky \& Gutiérrez (1998), Gutiérrez \& } \\
\text { Martorelli (1999a, b), Santos et al. (2007), } \\
\text { Monteiro et al. (2010) }\end{array}$ \\
\hline $\begin{array}{l}\text { Demidospermus } \\
\text { armostus }\end{array}$ & PM & Gill & $\begin{array}{l}\text { Argentina } \\
\text { and Brazil }\end{array}$ & $\begin{array}{c}\text { Gutiérrez \& Martorelli (1999a, b), Cohen \& } \\
\text { Kohn (2008), Azevedo et al. (2010), Monteiro } \\
\text { et al. (2010) }\end{array}$ \\
\hline
\end{tabular}


Table V. Continuation

\begin{tabular}{|c|c|c|c|c|}
\hline Parasites & Host & $\begin{array}{l}\text { infection / } \\
\text { infestation }\end{array}$ & Locality & Reference \\
\hline $\begin{array}{l}\text { Demidospermus } \\
\text { majusculus }\end{array}$ & PM & Gill & Brazil & Santos et al. (2007) \\
\hline $\begin{array}{l}\text { Demidospermus } \\
\text { ichthyocercus }\end{array}$ & PM & Gill & Brazil & Monteiro et al. (2010) \\
\hline $\begin{array}{l}\text { Demidospermus } \\
\text { leptosynophallus }\end{array}$ & PM & Gill & Brazil & Azevedo et al. (2010) \\
\hline $\begin{array}{l}\text { Pavanelliella } \\
\text { pavanellii }\end{array}$ & PM & Nasal cavity & Brazil & Brasil-Sato \& Pavanelli (2000) \\
\hline $\begin{array}{l}\text { Pavanelliella } \\
\text { takemotoi }\end{array}$ & PM & Nasal cavity & Brazil & Aguiar et al. (2011) \\
\hline Unibarra sp. & PM & Gill & Brazil & Takemoto et al. (2009) \\
\hline $\begin{array}{l}\text { Unibarra } \\
\text { paranoplatensis }\end{array}$ & PM & Gill & Argentina & $\begin{array}{l}\text { Suriano \& Incorvaia (1995), Negreiros et al. } \\
\qquad(2019)\end{array}$ \\
\hline Scleroductus sp. & $\begin{array}{l}\mathrm{PM} / \\
\mathrm{RQ}\end{array}$ & Gill & Brazil & $\begin{array}{l}\text { Kritsky et al. (1995, 2013), Ferrari-Hoeinghaus } \\
\text { et al. (2006), Santos et al. (2007) }\end{array}$ \\
\hline $\begin{array}{l}\text { Scleroductus } \\
\text { yuncensi }\end{array}$ & PM & Gill & Argentina & Gutiérrez \& Martorelli (1999a, b) \\
\hline Kritskyia moraveci & $\mathrm{RQ}$ & $\begin{array}{l}\text { Urinary bladder and } \\
\text { ureters }\end{array}$ & Brazil & Kohn (1990) \\
\hline $\begin{array}{l}\text { Urocleidoides } \\
\text { mastigatus }\end{array}$ & $\mathrm{RQ}$ & Gill & Brazil & Ferrari-Hoeinghaus et al. (2006) \\
\hline $\begin{array}{l}\text { Gyrodactylus } \\
\text { lilianae }\end{array}$ & $\mathrm{RQ}$ & $\begin{array}{l}\text { Surface, fins and } \\
\text { barbels }\end{array}$ & Brazil & Razzolini et al. (2019) \\
\hline \multicolumn{5}{|c|}{ Myxozoan } \\
\hline Henneguya sp. & PM & Gill & Brazil & $\begin{array}{c}\text { Martins et al. (2004), Bachmann et al. (2007), } \\
\text { Santos et al. (2007) }\end{array}$ \\
\hline Henneguya rhamdia & $\mathrm{RQ}$ & Gill & Brazil & Matos et al. (2005) \\
\hline Henneguya jundiai & $\mathrm{RQ}$ & Gill & Brazil & Negrelli et al. (2019) \\
\hline Myxobolus sp. & PM & Gill & Brazil & Cordeiro et al. (1989) \\
\hline Myxobolus absonus & PM & $\begin{array}{l}\text { Gill and } \\
\text { opercular cavity }\end{array}$ & Brazil & Cellere et al. (2002), Santos et al. (2007) \\
\hline $\begin{array}{l}\text { Myxobolus } \\
\text { marajoensis }\end{array}$ & $\mathrm{RQ}$ & Intestine & Brazil & Abrunhosa et al. (2017) \\
\hline \multicolumn{5}{|c|}{ Nematoda } \\
\hline $\begin{array}{c}\text { Rhaphidascaris } \\
\text { (Sprentascaris) } \\
\text { pimelodi }\end{array}$ & PM & Intestine & Paraguay & Petter \& Cassone (1984) \\
\hline $\begin{array}{l}\text { Spinitectus } \\
\text { sternopygi }\end{array}$ & PM & - & - & Thatcher (1991) \\
\hline Cucullanus sp. & $\begin{array}{l}\mathrm{PM} / \\
\mathrm{RQ}\end{array}$ & Intestine & Brazil & $\begin{array}{c}\text { Brasil-Sato (2003), Azevedo et al. (2010), } \\
\text { Luque et al. (2011) }\end{array}$ \\
\hline Cuccullanus patoi & PM & Intestine & Brazil & Fortes et al. (1992), Luque et al. (2011) \\
\hline
\end{tabular}


Table V. Continuation

\begin{tabular}{|c|c|c|c|c|}
\hline Parasites & Host & $\begin{array}{l}\text { infection / } \\
\text { infestation }\end{array}$ & Locality & Reference \\
\hline $\begin{array}{l}\text { Cucullanus } \\
\text { fabregasi }\end{array}$ & PM & Intestine & Brazil & Fortes et al. (1993a), Luque et al. (2011) \\
\hline $\begin{array}{l}\text { Cucullanus } \\
\text { riograndensis }\end{array}$ & PM & Intestine & Brazil & Fortes et al. (1993b), Luque et al. (2011) \\
\hline Cucullanus debacoi & PM & Intestine & Brazil & Sarmento et al. (1995), Luque et al. (2011) \\
\hline Cucullanus pinnai & $\begin{array}{l}\mathrm{PM} / \\
\mathrm{RQ}\end{array}$ & $\begin{array}{l}\text { Stomach, celomatic } \\
\text { cavity, intestine }\end{array}$ & Brazil & $\begin{array}{c}\text { Vicente \& Pinto (1999), Brasil-Sato (2003), } \\
\text { Santos et al. (2007), Albuquerque et al. } \\
\text { (2008), Takemoto et al. (2009), Venancio et al. } \\
\text { (2010) }\end{array}$ \\
\hline Contracaecum sp. & $\begin{array}{l}\mathrm{PM} / \\
\mathrm{RQ}\end{array}$ & $\begin{array}{l}\text { Mesentery, gonada, } \\
\text { stomach, intestine } \\
\text { and liver }\end{array}$ & Brazil & $\begin{array}{c}\text { Brasil-Sato (2003), Madi \& Silva (2005), } \\
\text { Takemoto et al. (2009), Azevedo et al. (2010), } \\
\text { Dias et al. (2016) }\end{array}$ \\
\hline Goezia sp. & PM & Intestine & Brazil & Brasil-Sato (2003), Takemoto et al. (2009) \\
\hline Goezia spinulosa & PM & Stomach & - & Luque et al. (2011) \\
\hline Dichelyne sp. & PM & Intestine & Brazil & Brasil-Sato (2003) \\
\hline Dichelyne pimelodi & PM & Intestine & Brazil & $\begin{array}{c}\text { Moravec et al. (1997), Bachmann et al. (2007), } \\
\text { Luque et al. (2011) }\end{array}$ \\
\hline Philometra sp. & PM & - & Brazil & Brasil-Sato (2003), Takemoto et al. (2009) \\
\hline Monhysterides sp. & PM & Intestine & Brazil & Takemoto et al. (2009) \\
\hline $\begin{array}{l}\text { Procamallanus } \\
\text { (Spirocamallanus) } \\
\text { sp. }\end{array}$ & PM & Intestino & Brazil & Vicente \& Pinto (1999), Takemoto et al. (2009) \\
\hline $\begin{array}{l}\text { Procamallanus } \\
\text { (Spirocamallanus) } \\
\quad \text { freitasi }\end{array}$ & PM & Intestine & Brazil & Brasil-Sato (2003) \\
\hline $\begin{array}{l}\text { Procamallanus } \\
\text { (Spirocamallanus) } \\
\quad \text { pimelodus }\end{array}$ & PM & Intestino & Brazil & Bachmann et al. (2007) \\
\hline $\begin{array}{l}\text { Procamallanus } \\
\text { (Spirocamallanus) } \\
\text { rarus }\end{array}$ & PM & Intestino & - & Yamada \& Takemoto (2013) \\
\hline $\begin{array}{l}\text { Procamallanus } \\
\text { (Spirocamallanus) } \\
\text { hilarii }\end{array}$ & $\mathrm{RQ}$ & - & - & Luque et al. (2011) \\
\hline Eustrongylides sp. & PM & Body cavity & Brazil & Brasil-Sato (2003), Takemoto et al. (2009) \\
\hline Rondonia rondoni & PM & - & - & Luque et al. (2011) \\
\hline $\begin{array}{l}\text { Rhabdochona } \\
\text { uruyeni }\end{array}$ & PM & Intestine & Brazil & Azevedo et al. (2010) \\
\hline $\begin{array}{l}\text { Rhabdochona } \\
\text { kidderi }\end{array}$ & $\mathrm{RQ}$ & - & Mexico & Moravec et al. (2012) \\
\hline Capillariidae gen. sp. & $\mathrm{RQ}$ & - & Brazil & Azevedo et al. (2010) \\
\hline $\begin{array}{l}\text { Hysterothylacium } \\
\text { sp. }\end{array}$ & $\mathrm{RQ}$ & $\begin{array}{l}\text { Stomach and } \\
\text { intestine }\end{array}$ & Brazil & Dias et al. (2016) \\
\hline
\end{tabular}

$\mathrm{PM}=$ Pimelodus maculatus; $\mathrm{RQ}=$ Rhamdia quelen. 


\section{CONCLUSION}

The nematode of the genus Contracaecum sp., which has zoonotic potential, was collected parasitizing $R$. quelen. However, greater attention should be paid to this parasite in $R$. quelen, as this fish has economic importance for fishing and has been used in the preparation of "sushi" and "sashimi", therefore, if Contracaecum sp. parasitizes these fish, they can cause consequences in humans depending on the way the fish is consumed, presenting the symptoms already discussed previously. We can observe different groups of parasites in both P. maculatus and $R$. quelen; however, ectoparasites were predominant in the two host species. Some of the parasites had their first registration in the host, as the Isopoda Riggia sp. is a new record for the host $P$. maculatus and A. robustus is a new record for the host $R$. quelen and all the parasites collected in the two species of fish are new records for the Jacaré-Pepira River, Ibitinga.

\section{Acknowledgments}

We would like to thank the students David Minaya and Jorge Luis Mendoza, the Laboratorio de Ecología y Biodiversidad Animal (LEBA) and the Universidad Nacional Federico Villarreal (UNFV) from Peru for all their support during internship abroad accomplished through the Bolsa Estágio de Pesquisa no Exterior (BEPE). We thank the Fundação de Amparo à Pesquisa do Estado de São Paulo (FAPESP) (Processes no 2016/01587-3 and $n^{\circ}$ 2017/17085-0) for the scientific and financial support.

\section{REFERENCES}

ABRUNHOSA J, SINDEAUX-NETO JL, DOS SANTOS AK, HAMOY I \& MATOS E. 2017. Myxobolus marajoensis sp. n. (Myxosporea: Myxobolidae), parasite of the freshwater catfish Rhamdia quelen from the Brazilian Amazon region. Braz J Vet Parasitol 26: 465-471.

AGUIAR JC, CECARRELLI PJ \& LUQUE JL. 2011. Two new species of Pavanelliella (Monogenea, Dactylogyridae) parasitic on pimelodid fishes from Mogi Guaçú river, Southeastern
Brazil, and notes on the morphology of $P$. pavanellii. Neotrop Helminthol 5: 213-224.

ALBUQUERQUE MC, SANTOS MD, MONTEIRO CM, MARTINS AN, EDERLI NB \& BRASIL-SATO MC. 2008. Helmintos endoparasitos de Pimelodus maculatus Lacèpede, 1803, (Actinopterygii, Pimelodidae) de duas localidades (lagoa e calha do rio) do rio Guandu, estado do Rio de Janeiro, Brasil. Rev Bras Parasitol Vet 17: 113-119.

AMATO SB \& AMATO JFR. 1993. A new species of Phyllodistomum Braun, 1899 (Digenea: Gorgoderidae) from Rhamdia quelen (Quoy \& Gaimard, 1824) (Siluriformes: Pimelodidae). Mem Inst Oswaldo Cruz 88: 557-559.

ANAGUANO-YANCHA F \& BRITO JM. 2015. Parasitismo de Riggia sp. (Isopoda: Cymothoidae) en dos especies de peces Chaetostoma sp. y Rhamdia quelen del suroriente del Ecuador. Av Cienc Ing 7: 13-16.

ANDERSON RM \& GORDON DM. 1982. Processes influencing the distribution of parasite numbers within host populations with special emphasis on parasite-induced host mortalities. Parasitology 85: 373-398.

ARMAS DE CONROY G. 1986. Crocodilicola pseudostoma (Willemoes-Suhm, 1870) Poche, 1925 (Trematoda: Proterodiplostomatidae), endoparásito del bagre pimelódido Rhamdia hilarii Val., 1840 del Estado de São Paulo, Brasil. Rev Ibér Parasitol 46: 35-38.

AZEVEDO RK, ABDALLAH VD \& LUQUE JL. 2010. Acanthocephala, Annelida, Arthropoda, Myxozoa, Nematoda and Platylminthes parasites of fishes from the Guandu river, Rio de Janeiro, Brazil. Check List 6: 659-667.

BACHMANN F, GREINERT JA, BERTELLI PW, DA SILVA FILHO HH, DE LARA NOT, GHIRALDELLI L \& MARTINS ML. 2007. Parasitofauna de Pimelodus maculatus (Osteichthyes: Pimelodidae) do rio Itajaí-Açu em Blumenau, Estado de Santa Catarina, Brasil. Acta Sci Biol Sci 29: 109-114.

BELL G \& BURT A. 1991. The comparative biology of parasite species diversity: internal helminths of freshwater fish. J Anim Ecol 60: 1047-1064.

BIER JW. 1988. Anisakiasis. In: Balows A et al. (Eds), Laboratory Diagnosis of Infectious Diseases, New York: Springer, NY, p. 768-774.

BRASIL-SATO MC. 2003. Parasitos de peixes da bacia do São Francisco. In: Godinho HP and Godinho AL. Águas, peixes e pescadores do São Francisco das Minas Gerais, Belo Horizonte: PucMinas, p. 149-165.

BRASIL-SATO MC \& PAVANELLI GC. 1998. Neoechinorhynchus pimelodisp.n.(Eoacanthocephala,Neoechinorhynchidae) parasitizing Pimelodus maculatus Lacépede, 
"mandi-amarelo" (Siluroidei, Pimelodidae) From the Basin of the São Francisco River, Três Marias, Minas Gerais, Brazil. Rev Bras Zool 15: 1003-1011.

BRASIL-SATO MC \& PAVANELLI GC. 1999. Ecological and reproductive aspects of Neoechinorhynchus pimelodi (Eoacanthocephala, Neoechinorhynchidae) of Pimnelodus maculatus Lacepède (Siluroidei, Pimelodidae) of the São Francisco River, Brazil. Rev Bras Zool 16: 73-82.

BRASIL-SATO MC \& PAVANELLI GC. 2000. Pavanelliella pavanellii Kritsky and Boeger, 1998 (Monogenea: Dactylogyridae) parasito das cavidades nasais de Pimelodus maculatus Lac., 1803, "mandi", das bacias do Rio São Francisco e do Rio Paraná, Brasil. Parasitol Día 24: 123-126.

BRASIL-SATO MC \& PAVANELLI GC. 2004. Digenea de Pimelodus maculatus (Osteichthyes, Pimelodidae) das bacias dos rios São Francisco e Paraná, Brasil. Parasitol Latinoam 59: 123-131.

BRASIL-SATO MC, PAVANELLI GC \& LUQUE JL. 2000. Ocorrência e aspectos quantitativos de Gamispinus diabolicus (Copepoda: Ergasilidae) parasitando o mandi-amarelo, Pimelodus maculatus (Siluroidei: Pimelodidae), no Rio Paraná, Brasil. Rev Univ Rural Ciênc Vida 22: 67-69.

BUSH AO \& HOLMES JC. 1986. Intestinal helminths of lesser scaup ducks: an interactive community. Can J Zool 64: 142-152.

BUSH AO, LAFFERTY KD, LOTZ JM \& SHOSTAK AW. 1997. Parasitology meets ecology on its own terms. J Parasitol 83: 575-583.

CANHOS DAL, SOUSA-BAENA MS, DE SOUZA S, MAIA LC \& STEHMANN JR, CANHOS VP, DE GIOVANNI R, BONACELLI MBM, LOS W \& PETERSON AT. 2015. The Importance of Biodiversity E-infrastructures for Megadiverse Countries. PLoS Biol 13: e1002204.

CARVALHO AR, TAVARES LER \& LUQUE JL. 2009. A new species of Aphanoblastella (Monogenea: Dactylogyridae) parasitic on Rhamdia quelen (siluriformes: Heptapteridae) from Southeastern Brazil. Acta Sci Biol Sci 31: 323-325.

CARVALHO JN, SANTOS GC, PEREIRA FC, PAIVA A \& MOURA BL. 2010. Importância da Anisakidose como zoonose parasitária. In: Anais da Jornada de Ensino Pesquisa e Extensão - JEPEX, 10., Recife: Universidade Federal Rural de Pernambuco. (Unpublished).

CARVALHO RPS, TAKEMOTO RM, MELO CM, JERALDO VLS \& MADI RR. 2015. Structure of the parasite infracommunity of Sciades proops from the Japaratuba River Estuary, Sergipe, Brazil. Braz J Biol 75: 906-913.
CASWELL H. 1978. Predator-mediated coexistence: a nonequilibrium model. Am Nat 112: 127-154.

CELLERE EF, CORDEIRO NS \& ADRIANO EA. 2002. Myxobolus absonus sp. n. (Myxozoa: Myxosporea parasitizing Pimelodus maculatus (Siluriformes: Pimelodidae), a South American Freshwater fish. Mem Inst Oswaldo Cruz 97: 79-80.

CHAMBRIER A \& VAUCHER C. 1999. Proteocephalidae et Monticellidae (Eucestoda: Proteocephalidea) parasites de poissons d'eau au Paraguay, avec descriptions d'um genre nouveau et de dix espèces nouvelles. Rev Suisse Zool 106: 165-240.

CHAO D. 1985. Survey of Anisakis larvae in marine fish of Taiwan. Int J Zoonoses 12: 233-237.

CHEMES SB \& BRUSA RG. 2013. Description of Quadrigyrus machadoi (Fabio, 1983) (Acanthocephala, Quadrigyridae) in native fish of Wetlands associated with the San Javier River, Santa Fé, Argentina. Neotrop Helminthol 7: 187-194.

COHEN SC \& KOHN A. 2008. New data on species of Demidospermus (Dactylogyridae: Monogenea) parasitizing fishes from the Reservoir of the Itaipú Hydroelectric Power Station, Paraná State, Brazil, with new synonymies. Rev Bras Parasitol Vet 17: 167-170.

COMITÊ DA BACIA HIDROGRÁFICA DO TIETÊ-JACARÉ. 2015. Relatório de situação dos recursos hídricos 2015: UGRHI13 - Bacia Hidrográfica Tietê-Jacaré. Araraquara. [online]. 2015 [Accessed on January 6, 2018]. Available in: http://www.sigrh.sp.gov.br/public/uploads / deliberation/\%5C8046/deliberacao-cbh-tj-07-de-16-dedezembroeleicoes-2015.pdf.

CORDEIRO NS, GIOIA I \& CELLERE EF. 1989. Myxosporean parasites of Pimelodus maculatus Lacépède, 1803. V Reuniäo Sociedade Brasileira de Protozoológica, Caxambu. Mem Inst Oswaldo Cruz 11: 84-170.

CRUZ AR, SOUTO PCS, FERRARI CKB, ALLEGRETTI SM \& ARRAISSILVA WW. 2010. Endoscopic imaging of the first clinical case of anisakidosis in Brazil. Sci Parasitol 11: 97-100.

DIAS FJE, CLEMENTE SCS \& KNOFF M. 2010. Nematoides anisaquídeos e cestoides Trypanorhyncha de importância em saúde pública em Aluterus monoceros (Linnaeus, 1758) no Estado do Rio de Janeiro, Brasil. Rev Bras Parasitol Vet 19: 94-97.

DIAS JC, POZZA A, PESENTI TC, PEREIRA JR J \& BERNE MEA. 2016. Helmintos parasitos de Rhamdia quelen (Quoy \& Gaimard, 1824) no Sul do Brazil. Sci Anim Health 4: 2-20.

DOGIEL VA. 1961. Ecology of the parasites of freshwater fishes. In: Dogiel VA et al. (Eds), Parasitology of fishes, Leningrad: University Press, p. 1-47. 
EIRAS JC, TAKEMOTO RM \& PAVANELLI GC. 2006. Métodos de estudo e técnicas laboratoriais em parasitologia de peixes, $2^{\text {nd }}$ ed., Maringá: Eduem, 199 p.

ENGERS KB. 2000. Ergasilus thatcheri n. sp. (Copepoda, Poecilostomatoida, Ergasilidae) from the gills of Rhamdia quelen (Teleostei, Siluriformes, Pimelodidae) from Southern Brazil. J Parasitol 86: 945-947.

FEI ACY, LIN DS, WU TM, MAR PH \& PONG YM. 2004. Endoparasites of cetaceans stranded along coasts of Taiwan and Penghu. Bioformosa 39: 49-53.

FERRARI-HOEINGHAUS AP, TAKEMOTO RM, OLIVEIRA LC, MAKRAKIS MC \& BAUMGARTNER G. 2006. Host-parasite relationships of monogeneans in gills of Astyanax altiparanae and Rhamdia quelen of the São Francisco Verdadeiro River, Brazil. Parasite 13: 315-320.

FONTENELLE G, KNOFF M, FELIZARDO NN, TORRES EJL, LOPES LMS \& GOMES DC \& DE SÃO CLEMENTE SC. 2015. Anisakidae and Raphidascarididae larvae parasitizing Selene setapinnis (Mitchill, 1815) in the State of Rio de Janeiro, Brazil. Rev Bras Parasitol Vet 24: 72-77.

FORTES E, HOFFMANN RP \& SARMENTO TM. 1992. Descrição de Cucullanus patoi sp.n. (Nematoda, Cucullanidae) de pintado Pimelodus maculatus Lacépède, 1803 (Pisces), do Lago do Guaíba, RS, Brasil. Cienc Rural 22: 325-328.

FORTES E, HOFFMANN RP \& SARMENTO TM. 1993a. Cucullanus fabregasi sp. n.: Nematoda parasita do intestino do peixe Pimelodus maculatus Lacépède, 1803 do Rio Guaíba, Porto Alegre, Rio Grande do Sul, Brasil. Arq Fac Vet UFRGS 21: 71-76.

FORTES E, HOFFMANN RP \& SARMENTO TM. 1993b. Nova espécie de nematódeo Cucullanus, C. riograndensis sp. n. de Pimelodus maculatus Lacépède, 1803 do Lago do Guaíba, Rio Grande do Sul, Brasil. Rev Bras Med Vet 15: 79-82.

FROESE R \& PAULY D. 2018. FishBase. World Wide Web electronic publication. [www.fishbase.org], version (06/2018).

FURTADO WE, CARDOSO L, FIGUEREDO AB, MARCHIORI NC \& MARTINS ML. 2019. Histological and hematological alterations of silver catfish Rhamdia quelen highly parasitized by Lernaea cyprinacea. Dis Aquat Org 135: 157-168.

GRABDA J. 1983. Studies on viability and infectivity of Anisakis simplex stage III larvae in fresh salted and spiced Baltic herring. Acta Ichthyol 13: 117-129.

GUTIÉRREZ PA \& MARTORELLI SR. 1999a. Niche preferences and spatial distribution of Monogenea on the gills of
Pimelodus maculatus in Rio de la Plata (Argentina). Parasitology 119: 183-188.

GUTIÉRREZ PA \& MARTORELLI SR. 1999b. The structure of the monogenean community on the gills of Pimelodus maculatus in Rio de la Plata (Argentina). Parasitology 119: 177-182.

HALVORSEN O. 1971. Studies of helminth fauna of Norway. XVII. On the composition of the parasite fauna of coarse fish in the river Glomma, South-eastern Norway. Norwegian J Zool 19: 181-192.

HANSKI I. 1982. Dynamics of regional distribution: the core and satellite species hypothesis. Oikos 38: 210-221.

HANSKI I. 1991. Structured models of metapopulation dynamics. Biol J Linnean Soc 42: 57-71.

IGLESIAS R, D'AMELIO S, INGROSSO S, FARJALLAH S, MARTINEZCEDEIRA JÁ \& GARCIA-ESTEVEZ JM. 2008. Molecular and morphological evidence for the occurrence of Anisakis sp. (Nematoda, Anisakidae) in the Blainville's beaked whale Mesoplodon densirostris. J Helminthol 82: 305-308.

INGRAM JC. 2008. Berger-Parker Index. In: Encyclopedia ecology, $1^{\text {st }}$ ed., New York: Van Nostrand Reinhold, p. 332-334.

KENNEDY CR. 1982. Biotic fators. In: Fetterick MD \& Desser SS. Parasites their world and ours. Proceedings of the fifth International Congress of Parasitology, Amsterdam: The Netherlands: Elsevier Biomedical Press, p. 293-302.

KIM SG, JO YJ, PARK YS, KIM SH, SONG MH, LEE HH, KIM JS, RYOU JW, JOO JE \& KIM DH. 2006. Four cases of gastric submucosal mass suspected as anisakiasis. Korean J Parasitol 44: 81-86.

KOHN A. 1990. Kritskyia moraveci n. g., n. sp. (Monogenea: Dactylogyridae) from the urinary bladder and ureters of Rhamdia quelen (Quoy \& Gaimard, 1824) (Pisces: Pimelodidae) in Brazil. Syst Parasitol 17: 81-85.

KOHN A, FERNANDES BMM, GIBSON DI \& FRÓES OM. 1990. On the Brazilian species of halipegine genera (Trematoda: Derogenidae) from fishes, with new morphological data, hosts and synonyms. Syst Parasitol 16: 201-211.

KOHN A \& FRÓES OM. 1986. Saccocoeloides godoyi n. sp. (Haploporidae) and other trematodes parasites of fishes from the Guaíba Estuary, RS, Brazil. Mem Inst Oswaldo Cruz 81: 62-72.

KOZAČINSKI L, ZDOLEC N, HADŽIOSMANOVIĆ M, CVRTILA Ž \& FILIPOVIČ I. 2006. Assessment of parasitic invasions in fish meat on the Croatian market. MESO 7: 290-294.

KRITSKY DC, BOEGER WA, MENDOZA-FRANCO EF \& VIANNA RT. 2013. Neotropical Monogenoidea. 57. Revision and 
phylogenetic position of Scleroductus Jara \& Cone, 1989 (Gyrodactylidae), with descriptions of new species from the Guatemalan chulin Rhamdia guatemalensis (Gunther) (Siluriformes: Heptapteridae) in Mexico and the barred sorubim Pseudoplatystoma fasciatum (Linnaeus) (Siluriformes: Pimelodidae) in Brazil. Syst Parasitol 84: 1-15.

KRITSKY DC, BOEGER WA \& POPAZOGLO F. 1995. Neotropical Monogenoidea. 22. Variation in Scleroductus species (Gyrodactylidea, Gyrodactylidae) from siluriform fishes of southeastern Brazil. J Helminthol Soc Wash 62: 53-56.

KRITSKY DC \& GUTIÉRREZ PA. 1998. Neotropical Monogenoidea. 34. Species of Demidospermus (Dactylogyridae, Ancyrocephalinae) from the Gills of Pimelodids (Teleostei, Siluriformes) in Argentina. J Helminthol Soc Wash 65: 147-159.

LOPES MS, FERNANDES BMM, BASTOS OP, COHEN SC \& KOHN A. 2011. New hosts for two species of Acanthocephala of fishes from Paraná River, State of Paraná, Brazil. Rev Bras Zoociências 13: 29-32.

LUDWIG JA \& REYNOLDS JF. 1988. Statistical ecology. A primer on methods and computing, New York: WileyIntersciense Publication, 337 p.

LUQUE JL, AGUIAR JC, VIEIRA FM, GIBSON DI \& SANTOS CP. 2011. Checklist of Nematoda associated with the fishes of Brazil. Zootaxa 3082: 1-88.

LUQUE JL \& POULIN R. 2007. Metazoan parasite species richness in Neotropical fishes: Hotspots and the geography of biodiversity. Parasitology 134: 865-878.

LUQUE JL, VIEIRA FM, TAKEMOTO RM, PAVANELLI GC \& EIRAS JC. 2013. Checklist of Crustacea parasitizing fishes from Brazil. Check List 9: 1449-1470.

MADI RR \& SILVA MSR. 2005. Contracaecum Railliet \& Henry, 1912 (Nematoda, Anisakidae): o parasitismo relacionado à biologia de três espécies de peixes piscivoros no reservatório do Jaguari, SP. Rev Bras Zoociências 7: 15-24.

MAGURRAN AE. 1988. Diversidad ecológica y su medición, Barcelona: Vedrá, 200 p.

MARTINS ML, ONAKA EM, BOZZO FR \& FENERICK J. 2004. Henneguya sp. (Myxozoa: Myxobolidae) in Pimelodus maculatus (Osteichthyes: Siluridae) from Volta Grande Reservoir, Minas Gerais, Brazil. Bol Inst Pesca 30: 1-7.

MARTINS ML, ONAKA EM \& FENERICK J. 2005. Larval Contracaecum sp. (Nematoda: Anisakidae) in Hoplias malabaricus and Hoplerythrinus unitaeniatus (Osteichthyes: Erythrinidae) of economic importance in occidental marshlands of Maranhão, Brazil. Vet Parasitol 127: 51-59.
MATOS E, TAJDARI J \& AZEVEDO C. 2005. Ultrastructural studies of Henneguya rhamdia n. sp. (Myxozoa) a parasite from the Amazon teleost fish, Rhamdia quelen (Pimelodidae). J Eukaryot Microbiol 52: 532-537.

MATTIUCCI S, PAGGI L, NASCETTI G, PORTES SG, COSTA G \& DI BENEDITTO AP, RAMOS R, ARGYROU M, CIANCHI R \& BULLINI L. 2002. Genetic markers in the study of Anisakis typica (Diesing, 1860) larval identification and genetic relationships with other species of Anisakis Dujardin, 1845 (Nematoda: Anisakidae). Syst Parasitol 51: 159-170.

MONEO I, CABALLERO ML, GÓMEZ F, ORTEGA E \& ALONSO MJ. 2000. Isolation and characterization of a major allergen from the fish parasite Anisakis simplex. J Allergy Clin Immunol 106: 177-182.

MONTEIRO CM, KRITSKY DC \& BRASIL-SATO MC. 2010. Neotropical Monogenoidea. 55. dactylogyrids parasitising the pintado-amarelo Pimelodus maculatus Lacépède (Actinopterygii: Pimelodidae) from the Rio São Francisco, Brazil. Syst Parasitol 76: 179-190.

MORAIS NCM. 2005. Helmintos parasitos de Jundiá, Rhamdia quelen (Quoy \& Gaimard 1824) (Siluriformes) coletados em ambiente natural e em estação de piscicultura no sul do RS. Universidade Federal de Pelotas, Dissertação de Mestrado. (Unpublished).

MORAVEC F, KOHN A \& FERNANDES BMM. 1997. NeW observations on Seuratoid nematodes parasitic in fishes of the Paraná River, Brazil. Folia Parasitol 44: 209-223.

MORAVEC F, SALGADO-MALDONADO G, GONZÁLEZ-SOLÍS D \& CASPETA-MANDUJANO JM. 2012. Host-parasite relationships of Rhabdochona kidderi Pearse, 1936 (Nematoda: Rhabdochonidae) in fishes of the Lacantún River in the Lacandon rain forest of Chiapas State, southern Mexico, with a key to Mexican species of Rhabdochona Railliet, 1916. Syst Parasitol 82: 1-12.

NEGREIROS LP, OLIVEIRA MSB \& TAVARES-DIAS M. 2019. First record of Unibarra paranoplatensis Suriano \& Incorvaia, 1995 (Dactylogyridae: Monogenea) on Sorubim lima (Siluriformes: Pimelodidae) from Brazil. Braz J Vet Parasitol 28: 504-507.

NEGRELLI DC, VIEIRA DHMD, TAGLIAVINI VP, ABDALLAH VD \& DE AZEVEDO RK. 2019. Molecular and morphological analysis of Henneguya jundiai n. sp. (Cnidaria: Myxosporea), a new parasite of the gills of Rhamdia quelen in Brazil. Acta Trop 197: 105053.

NUNES C, LADEIRA S \& MERGULHÃo A. 2003. Alergia ao Anisakis simplex na população portuguesa. Rev Port Imunoalergologia 11: 30-40. 
NúÑEZ MO, ARREDONDO NJ \& PERTIERRA AAg. 2017. Adult Trematodes (Platyhelminthes) of freshwater fi shes from Argentina: a checklist. Rev Suisse Zool 124: 91-113.

PALM HW, DAMRIYASA IM, LINDA \& OKA IBM. 2008. Molecular genotyping of Anisakis Dujardin, 1845 (Nematoda: Ascaridoidea: Anisakidae) larvae from marine fish of Balinese and Javanese waters, Indonesia. Helminthologia 45: 3-12.

PAVANELLI GC \& MACHADO DOS SANTOS MHM. 1992. Goezeella agostinhoi sp. n. e Monticellia loyolai sp. n., cestoides proteocefalideos parasitas de peixes pimelodideos do rio Paraná, Brasil. Rev Bras Parasitol Vet 1: 45-50.

PAVANELLI GC, MACHADO MH, TAKEMOTO RM, GUIDELLI GM \& LIZAMA MAP. 2004. Helminth fauna of the fishes: diversity and ecological aspects. In: Thomaz SM et al. (Eds), The Upper Paraná River and its Floodplain: Physical aspects, Ecology and Conservation, $1^{\text {st }}$ ed., Leiden, p. 309-329.

PERTIERRA AAG. 1995. Nomimoscolex microacetabula sp. n. y N. pimelodi sp. n. (Cestoda: Proteocephalidea) parasitos de Siluriformes del Rio de la Plata. Neotrópica 41: 19-26.

PERTIERRA AAG. 2002. Redescription of Proteocephalus bagri and $P$. rhamdiae (Cestoda: Proteocephalidae), parasites of Rhamdia quelen (Siluriformes: Pimelodidae) from South America, with comments on morphological variation. Folia Parasitol 49: 55-66.

PERTIERRA AAG. 2004. Redescription of Monticellia magna (Rego, dos Santos \& Silva, 1974) (Eucestoda: Monticelliidae) parasite of Pimelodus spp. (Pisces: Siluriformes) from Argentina, and morphological study of microtriches. Rev Suisse Zool 11: 11-20.

PERTIERRA AAG, SPATZ L \& DOMA IL. 1996. Systematics an metapopulation dynamics of Pomphorhynchus sphaericus n. sp. (Acanthocephala: Pomphorhynchidae) from freshwater siluriform fishes in the subtropical region of Argentina. Res Rev Parasitol 56: 33-39.

PETTER A \& CASSONE J. 1984. Nematodes from fish in Paraguay.1. Ascaridoidea: Sprentascaris, n. gen. Rev Suisse Zool 91: 617-634.

RAMOS P. 2011. Anisakis spp. em bacalhau, sushi e sashimi: risco de infecção parasitária e alergia. Rev Port Ciênc Vet 110: 87-97.

RAZZOLINI E, MURARI AL, BALDISSEROTTO B \& BOEGER WA. 2019. Gyrodactylus lilianae n. sp. (Polyonchoinea: Gyrodactylidae) from Rhamdia quelen (Quoy \& Gaimard) (Siluriformes: Heptapteridae) from southern Brazil: a potential nuisance for aquaculture. Syst Parasitol 96: 407-415.
REIS RE, ALBERT JS, DI DARIO F, MINCARONE MM, PETRY P \& ROCHA LA. 2016. Fish biodiversity and conservation in South America. J Fish Biol 89: 12-47.

RODRIGUES MV, PANTOJA JCF, GUIMARÃES CDO, BENIGNO RNM, PALHA MDC \& BIONDI GF. 2015. Prevalence for nematodes of hygiene-sanitary importance in fish from Colares Island and Vigia, Pará, Brasil. Rev Bras Ciênc Vet 22: 124-128.

ROHDE K, HAYWARD C \& HEAP M. 1995. Aspects of the ecology of metazoan ectoparasites of marine fishes. Int J Parasitol 25: 945-970.

SAAD CDR \& LUQUE JL. 2009. Larvas de Anisakidae na musculatura do pargo, Pagrus pagrus, no estado do Rio de Janeiro, Brasil. Rev Bras Parasitol Vet 18: 71-73.

SANTOS DS \& ALVES DR. 2016. Ocorrência de Anisakis simplex (nematoda: anisakidae) em bacalhau comercializado em Volta Redonda, Rio de Janeiro, Brasil. Cad UniFOA 11: 131-140.

SANTOS MD, LEMOS-PITA SRLDC \& BRASIL-SATO MC. 2007. Metazoan parasite fauna of Pimelodus maculatus Lacepède, 1803 (Siluriformes, Pimelodidae) from the Guandu river, Rio de Janeiro State, Brazil. Brazil. Acta Sci Biol Sci 29: 101-107.

SARMENTO TM, FORTES E \& HOFFMANN RP. 1995. Cucullanus debacoi sp. n. Nematoda, parasito do intestino do Pimelodus maculatus Lacépède, 1803 (Pisces, Pimelodidae) do rio Guaíba, Porto Alegre, Rio Grande do Sul. A Hora Vet 15: 38-40.

SERRANO TD, PELEGRINI L, SANTIAGO ET, PRADO FD, PORTOFORESTI F, AZEVEDO RK \& ABDALLAH VD. 2017. Molecular identification and morphological characterization of anisakis spp. L3 larvae (Nematoda: Anisakidae) in Scomber colias Gmelin, 1789 (Perciformes: Scombridae) from the North of Argentina. Neotrop Helminthol 11: 25-36.

SHAMSI S, TURNER A \& WASSENS S. 2018. Description and genetic characterization of a new Contracaecum larval type (Nematoda: Anisakidae) from Australia. J Helminthol 92: 216-222.

SOUZA ME, CARDOSO EO, LEAL LA, LIMA TMP \& TOLEDO RCC. 2016. Anisakidose humana: zoonose com risco potencial para consumidores de pescado cru. Vet Zootec 23: 25-37.

SU YC \& FEI ACY. 2004. Endoparasites of the crested goshawk, Accipiter trivirgatus formosae, from Taiwan, Republic of China. Comp Parasitol 71: 178-183.

SURIANO DM \& INCORVAIA IS. 1995. Ancyrocephalid (Monogenea) parasites from siluriform fishes from the Paranean-Platean ichthyogeographical Province in Argentina. Acta Parasitol 40: 113-124. 
TAKEMOTO RM, PAVANELLI GC, LIZAMA MAP, LACERDA ACF, YAMADA FH, MOREIRA LHA, CESCHINI TL \& BELLAY S. 2009. Diversity of parasites of fishes from the Upper Paraná River floodplain, Brazil. Braz J Biol 69: 691-705.

THATCHER VE. 1991. Amazon Fishes Parasites. Manaus: Instituto Nacional de Pesquisas da Amazônia. Amazoniana, p. 263-572.

THATCHER VE. 2006. Amazon Fish Parasites, $2^{\text {nd }}$ ed., Moscow: Pensoft Publishers, p. 508.

THATCHERV \& BRASIL-SATO MC. 2008. Ergasilus chelangulatus sp. nov. (Copepoda: Ergasillidae) a branchial parasite of the freshwater catfish, Pimelodus maculatus from upper São Francisco River, Brazil. Rev Bras Zool 25: 512-514.

TORRES P, MOYA R \& LAMILLA J. 2000. Nematodos anisákidos de interés en salud pública en peces comercializados en Valdivia, Chile. Arch Med Vet 32: 107-113.

VENANCIO ACP, AGUIAR GR, LOPES OS \& ALVES DR. 2010. Metazoan parasites of Mandi-amarelo Pimelodus maculatus and of Jundiá Rhamdia quelen (Osteichthyes: Siluriformes) of Paraiba do Sul River, Volta Redonda, Rio de Janeiro. Rev Bras Parasitol Vet 19: 157-163.

VIANNA RT, JÚNIOR JP \& BRANDÃO DA. 2005. Clinostomum complanatum (Digenea, Clinostomidae) density in Rhamdia quelen (Siluriformes, Pimelodidae) from South Brazil. Braz Arch Biol Technol 48: 635-642.

VICENTE JJ \& PINTO RM. 1999. Nematoides do Brasil: Nematoides de Peixes Atualização 1985-1998. Rev Bras Zool 16: 561-610.

VON ZUBEN CJ. 1997. Implicações da agregação espacial de parasitas para a dinâmica populacional na interação hospedeiro-parasita. Rev Saúde Pública 31: 523-530.

WOOTTEN R. 1973. The metazoan parasite-fauna of fish from Hanningfield Reservoir, Essex inrelation to features of the habitat and host populations. J Zool 171: 323-331.

YAMADA FH \& TAKEMOTO RM. 2013. Metazoan parasite fauna of two peacock-bass cichlid fish in Brazil. Check List 9: 1371-1377.

ZAR JH. 1999. Biostatistical Analysis, $4^{\text {th }}$ ed., New Jersey: Prentice Hall, USA, p. 46.

\section{How to cite}

NEGRELLI DC, IANNACONE J, ABDALLAH VD \& DE AZEVEDO RK. 2021. Qualitative and quantitative study of parasites of Pimelodus maculatus and Rhamdia quelen from the Jacaré-Pepira River, state of São Paulo, Brazil. An Acad Bras Cienc 93: e20190571. DOI 10.1590/00013765202120190571.
Manuscript received on May 17, 2019;

accepted for publication on March 16, 2020

\section{DÉBORA C. NEGRELLI ${ }^{1}$}

https://orcid.org/0000-0001-7907-8609

\section{JOSÉ IANNACONE ${ }^{2,3}$}

https://orcid.org/0000-0003-3699-4732

\section{VANESSA D. ABDALLAH}

https://orcid.org/0000-0001-6539-6091

\section{RODNEY K. DE AZEVEDO 4}

https://orcid.org/0000-0002-0471-6079

"Universidade Estadual Paulista "Júlio de Mesquita Filho" (UNESP), Instituto de Biociências, Departamento de Bioestatística, Biologia Vegetal, Parasitologia e Zoologia, Setor Parasitologia, Rua Professor Doutor Antônio Celso Wagner Zanin, 250, 18618-689 Botucatu, SP, Brazil

${ }^{2}$ Universidad Nacional Federico Villarreal (UNFV), Laboratorio de Ecología y Biodiversidad Animal (LEBA), Facultad de Ciencias Naturales y Matemática, Grupo de Investigación en Sostenibilidad Ambiental, Escuela Universitaria de Posgrado, Jr. Río Chepén, 290, 15007 El Agustino, Lima, Peru

${ }^{3}$ Universidad Cientifica del Sur, Carr, Laboratorio de Ingeniería Ambiental, Carrera de Ingeniería Ambiental, Panamericana Sur, Km 19, 15067 Villa El Salvador, Lima, Peru

${ }^{4}$ Programa de Pós-Graduação em Análise de Sistemas Ambientais, Centro Universitário CESMAC, Rua Professor Ângelo Neto, 50, 57051-530 Maceió, AL, Brazil

Correspondence to: Rodney Kozlowiski de Azevedo E-mail: azevedork@gmail.com

\section{Author contributions}

Negrelli DC performed fish analysis, parasite processing and revised the manuscript. Iannacone J performed the statistical analyzes and revised the manuscript. Abdallah VD \& Azevedo RK constituted and revised the manuscript, as well as, identified the species of parasites found.

\section{(cc) BY}

